\title{
Penerapan metode eksperimen mencampur warna dengan media cat air di TK Aisyiyah Pekalongan
}

\author{
Anna Diana Shanty \\ TK Qurrota A'yun 01 Aisyiyah, Kota Pekalongan
}

\begin{tabular}{|c|c|}
\hline Article Info & ABSTRACT \\
\hline Article history: & \multirow{3}{*}{$\begin{array}{l}\text { Activities that involve students directly are very meaningful, especially } \\
\text { activities that can develop children's talents and interests. The background of } \\
\text { this research is that there are still many children who do not know how to mix } \\
\text { colors. In this case the method with experiments and media with watercolors } \\
\text { The research method used is Classroom Action Research (CAR) with two } \\
\text { cycles. In each cycle consists of: planning, implementation, observation and } \\
\text { reflection. The subjects of this study were the children of the B3 group of TK } \\
\text { Aisyiyah Pekalongan, totaling } 16 \text { children. The results of the research on pre- } \\
\text { cycle activities were } 57.19 \text {. In the first cycle, mixing colors was } 74,69 \\
\text { Meanwhile, in the second cycle, the children got an average score of } 81,87 \\
\text { This shows that the value of the child has increased from the pre-cycle } \\
\text { activities I was } 17.50 \text { and the second cycle was } 7.18 \text {. The expected } \\
\text { development achievement in Pre-cycle activities is only } 14.58 \% \text {. }\end{array}$} \\
\hline $\begin{array}{l}\text { Received : } 30 \text { Juli } 2021 \\
\text { Revised : } 2 \text { September } 2021 \\
\text { Accepted : } 18 \text { September } 2021\end{array}$ & \\
\hline $\begin{array}{l}\text { experimental method; mix; color; } \\
\text { media; watercolor }\end{array}$ & \\
\hline
\end{tabular}

(*) Corresponding Author:

annadiana345@gmail.com

How to Cite: Shanty, A.D. (2021). Penerapan metode eksperimen mencampur warna dengan media cat air di TK Aisyiyah Pekalongan. Action Research Journal, 1(1): 13-18.

\section{PENDAHULUAN}

Anak usia dini sebagai sumber belajar karena anak usia dini khususnya anak yang berusia 0-6 tahun berada dalam masa keemasan( golden age ) di sepanjang rentang usia perkembangan manusia. Kita selaku orang tua seyogyanya memberikan kebebasan dalam berfikir dan berkreasi dengan berbagai media dan alat yang mereka dapatkan dari lingkungan sekitarnya. Hal ini tentunya menjadi awal yang baik dalam memberikan kebebasan dalam bereksplorasi di sekitar anak. Kita orang tua dan guru sebatas sebagai fasilitator salah satunya sebagai penyedia media belajar. Seperti yang disampaikan oleh Montessori (Yuliani, 2011: 54) bahwa masa pada anak usia dini merupakan periode sensitif (sensitive periods), selama masa ini anak secara khusus mudah menerima stimulus-stimulus dari lingkungannya.

Masa usia dini ini sebagai pondasi tumbuh kembang anak selanjutnya, sehingga jadikan anak-anak yang bahagia. Karena sebagai dasar keberhasilannya di masa yang akan datang ataupun sebaliknya dengan harapan pertumbuhan dan perkembangan anak akan mencapai optimalisasi. Hal ini sesuai pendapat dari Lili \& Nirwanasari, 2016:32) yang menyatakan bahwa pendidikan anak usia dini dalam aspek perkembangannya dapat dioptimalkan berupa fisik dan psikis yang meliputi perkembangan intelektual/ kognitif, bahasa, motorik dan sosial emaosional.

Oleh karena itu perlu adanya situasi dan kondisi yang kondusif pada saat memberikan stimulasi dan upaya pendidikan yang sesuai dengan kebutuhan dan minat anak.Tugas utama seorang pendidik dalam proses pembelajaran dimana pendidik mampu membangkitkan aktivitas belajar anak. Adapun pengelolaan salah satu diantaranya adalah dengan melakukan perencanaan sebagai bentuk antisipasi dan memperkirakan apa yang akan dilakukan dalam proses pembelajaran. Selanjutnya pendidik bertanggung jawab untuk melaksanakan kegiatan pembelajaran sesuai rencana dengan penuh tanggung jawab.

Salah satu perkembangan intelektual/ kognitif yakni pengenalan warna usia 4-6 tahun masih banyak yang belum mampu.Hal ini disebabkan oleh faktor yang mempengaruhinya yakni 
faktor internal dan faktor eksternal (Thidonanto, 2015: 65). Rahima (2017:65) menyampaikan bahwa perkembangan kogniif dalam mengenal warna di pengaruhi oleh bakat dan minat anak. Salah satu dari perkembangan kognitif yakni pengenalaan warna dipengaruhi oleh bakat dan minat ( Rahima, 2017:65)

Perkembangan kognitif yang merupakan dasar pembentukan gaya berfikir anak untuk mendapatkan konsep yang nyata ( Nina, el, 2016: 2). Untuk itu dalam pengenalan warna kepada anak usia dini diperlukan cara/ metode pembelajaran yang sesuai dengan karakteristik anak dan materi. Pendidik dalam memilih strategi pembelajaran diharapkan yang tepat, sehingga dapat membuat proses pembelajaran lebih interaktif, menarik, dan menyenangkan.

Seharusnya anak diberikan kesempatan untuk melakukan eksperimen dalam proses pembelajaran, yang mana hal ini merupakan salah satu cara untuk mendorong pengetahuan anak yang efektif. Adapun metode eksperimen yang mana mengaktifkan anak untuk mengamati dan percobaan secara mandiri guna membangun pengetahuan mereka. Pengamatan yang dilakukan denganeksperimen lebih intensif dibanding metode yang lain, selain itu metode eksperimen lebih mengeksplorasi keterlibatan siswa secara aktif dalam pembelajaran.

Ada beberapa penelitian yang serupa seperti yang dilakukan oleh Sukatmi (2011) pencampuran warna dengan media cat air mampu meningkatkan kemampuan daya kreatifitas pada anak TK di TK Kartika Surabaya. Ada juga Binti Taklimah (2015) mengambil judul Penerapan Pembelajaran dengan menggunakan metode eksperimen, dapat meningkatkan kemampuan kognitif dalam kegiatan menyebutkan macam-macam rasa pada anak kelompok B TK Dharma Wanita Pandansari Nganut Tulungagung.

Berdasarkan hasil observasi dan wawancara dengan guru pendamping, bahwa di TK Aisyiyah Pekalongan kemampuan anak dalam mencampur warna masih rendah. Hal ini disebabkan kurangnya pengetahuan tentang pengenalan warna primer (warna dasar), dan mengetahui warna sekunder ( hasil pencampuran warna primer ). Sedangkan metode eksperimen masih jarang dilakukan oleh pendidik dalam penugasan pengembangan kemampuan kognitif anak sehingga anak merasa jenuh, bosan dan tidak tertarik dengan kegiatan akibatnya keberhasilan pembelajaran belum maksimal. Untuk itu kegiatan mencampur warna perlu ditingkatkan lagi. Karena pencampuran warna dengan metode eksperimen dan menggunakan media cat air belum pernah dilakukan oleh TK Aisyiyah Pekalongan. Dengan harapan anak dapat mengetahui warna hasil campuran warna.

\section{METODE}

Penelitian ini menggunakan metode penelitian tindakan kelas ( PTK ). Adapun yang dilakukan peneliti adalah dengan dua siklus yang masing-masing, siklus I dilakukan pada bulan Juli 2021 selama 2 kali pertemuan dan siklus II pada bulan Agustus 2021 juga dua kali pertemuan. Subyek penelitian ini adalah anak kelompok B3 TK Aisyiyah Pekalongan. Sumber data berasal dari anak didik, guru kelas dan teman sejawat. Data yang dikumpulkan oleh peneliti berupa daftar kemampuan anak, catatan harian, hasil observasi dan saran dari peneliti yang dilakukan sebelum, selama, dan sesudah tindakan penelitian serta dokumentasi selama tindakan diberikan. Teknik yang dipakai dalam pengumpulan data berupa penilaian dan non tes. Penilaian digunakan untuk mengetahui kemampuan pencampuran warna. Teknik nontes berupa observasi dengan lembar observasi dan catatan harian untuk mengetahui aktivitas dan perubahan tingkah laku anak didik selama kegiatan dilakukan. Analisis data pada penelitian ini tersaji pada analisis kualitatif menggunakan metode pemaparan secara naratif komparatif, yakni menggambarkan seluruh temuan penelitian disertai menggunakan data-data kuantitatif yang dianalisis secara sederhana (prosentase). Adapun indikator penelitian ini antara lain: 1.anak mampu mengenal dan menyebutkan 12 warna, 2. Anak mampu menjawab warna yang ada di lingkungan sekitarnya, dan 3. anak mampu menyebutkan hasil pencampuran warna. Prosedur pada siklus I yakni pembelajaran yang dilakukan dengan apersepsi, penyampaian tujuan pembelajaran, dan penjelasan kegiatan yang akan dilakukan anak. Pelaksanaannya dimulai dengan 1) anak berkelompok, 2) anak mendengarkan penjelasan guru, 3) anak memperhatikan media yang 
digunakan guru, 4) anak melakukan pencampuran warna, 5) merefleksi pembelajaran. Prosedur perbaikan pada siklus II lebih meningkatkan kemampuan pencampuran warna dengan metode eksperimen dengan media cat air dan pendidik memberikan penilaian/skor hasil pencampuran warna.

\section{HASIL DAN PEMBAHASAN}

Hasil Pra Siklus

Hasil dari penelitian ini diperoleh dari tindakan prasiklus, siklus I dan siklus II.

Pada kegiatan prasiklus, didapatkan hasil kemampuan anak dalam kegiatan mencampur warna rata-rata 57,19 dengan ketuntasan $18,75 \%$. Dengan rincian rata-rata hasil yang diperoleh anak 915/16 anak $=57,19$ dan masuk dalam kategori cukup. Ketuntasan individu dengan skor maksimal 75 dicapai oleh 3 anak, dan ketuntasan klasikal dengan rata-rata 225/3 = 75 atau 18,75\% dari total anak yang ada.

1. Siklus I

Proses pembelajaran kemampuan pencampuran warna untuk mengenalkan warna dengan media cat air

Proses mengenalkan warna dengan cara mencampur warna menggunakan teknik eksperimen, antara lain : 1) intensifnya proses internalisasi kegiatan mencampur warna, 2) terjadinya penjelasan mengenai kegiatan mencampur warna, 3) intensifnya anak dalam berlatih mencampur warna dengan teknik eksperimen, 4) kondisi anak yang kondusif saat mencampur warna, 5) terbangunnya suasana yang rileks, sehingga anak terus mengikuti proses pembelajaran maaupun berlatih setelah proses pembelajaran. Proses pembelajaran dari awal sampai dengan akhir dilakukan sesuai dengan prosedur. Pada pertemuan akhir yang kedua, dilakukan pemberian penilaian pencampuran warna menggunakan teknik eksperimen dengan media pewarna cat air untuk mengetahui keberhasilan tindakan Siklus I.

Peningkatan kemampuan mencampur warna untk mengenalkan warna dengan teknik eksperimen menggunakan media pewarna cat air pada siklus I.

\begin{tabular}{cc} 
Tabel 1. Rekapitulasi Hasil Siklus I \\
\hline Kategori & Prosentase \\
\hline Sangat Baik & 31,25 \\
Baik & 37,50 \\
Cukup & 31,25 \\
Kurang & 0 \\
\hline
\end{tabular}

Berdasarkan Tabel 1, hasil rekapitulasi seluruh jumlah nilai kemampuan mencampur warna untuk mengenalkan warna menggunakan teknik eksperimen dengan media cat air, diketahui hasil siklus I rata-rata 75 dengan ketuntasan 68,75\% masuk dalam kategori baik. Adapun ketuntasan individu dengan skor maksimal 90 dicapai oleh 5 anak.

$\underline{\text { Refleksi Siklus I }}$

Setelah dilakukan pelaksanaan siklus I dan dianalisis hasilnya. Tujuan dari analisis tersebut adalah untuk mengetahui : 1) kekurangan dan kelebihan teknik dan media yang digunakan, 2) tindakan-tindakan anak selama proses pembelajaran, dan 3) tindakan-tindakan pendidik selama mengajar.Refleksi ini dilakukan guna mengubah strategi pembelajaran pada siklus II. Kelebihan siklus I ini adalah terdapatnya peningkatan respon dan aktivitas belajar anak sehingga meningkatkan kemampuan pencampuran warna. Adanya peningkatan sebesar 17,50 dari prasiklus, hal ini karena adanya kegiatan pencampuran warna menggunakan metode eksperimen dan dengan media cat air. Namun pembelajaran ini masih perlu ditingkatkan lagi agar nilai ratarata 74,69 yakni nilai rata-rata 80 sesuai target.

2. Siklus II

Proses kegiatan mencampur warna untuk mengenalkan warna dengan metode eksperimen menggunakan media cat air. 
Kegiatan awal membuat rencana pembelajaran yang didalamnya terdapat skenario perbaikan siklus I. Pada kegiatan Inti ada inovasi model pembelajaran dengan metode bercerita dengan media gambar. Proses pembelajaran yang terdiri dari aspek intensifnya proses internalisasi melakukan pencampuran warna, ada 13 anak yang memperhatikan atau sebesar $81,25 \%$ dan masuk kategori sangat baik. Aspek proses penjelasan yang kondusif mengenai pencampuran warna menggunakan teknik eksperimen dengan media cat air, terdapat 14 anak didik yang memperhatikan atau sebesar $87,50 \%$ dan termasuk dalam kategori sangat baik. Aspek proses anak berlatih pencampuran warna dengan cat air sehingga mampu menyebutkan 12 warna dengan dampingan pendidik, ada 14 anak yang memperhatikan atau sebesar 87,50\% dan masuk kategori sangat baik. Aspek kondusifnya anak dalam menyebutkan warna hasil pencampuran ada 15 anak atau sebesar $93,75 \%$ dan masuk kategori sangat baik. Aspek terbangunnya suasana rileks terdapat 15 anak atau sebsar $97,75 \%$, dan termasuk dalam kategori sangat baik.

Peningkatan kemampuan mencampur warna untuk mengenalkan warna dengan metode eksperimen dengan media cat air.

Rekapitulasi hasil kemampuan mencampur warna menggunakan metode eksperimen dangan media cat air pada siklus I dari semua aspek yakni : rata-rata nilai yang diperoleh anak $81,56 \%$ dan masuk dalam kategori baik. Ketuntasan individu dengan skor maksimal 90 dicapai oleh 8 anak. Ketuntasan klasikal dengan rata-rata 83 atau 93,75\%.

Perilaku anak selama proses kemampuan mencampur warna dengan metode eksperimen menggunakan media cat air.

Pada siklus II ini ada beberapa perilaku anak yang tergambar melalui kegiatan observasi, jurnal pendidik dan wawancara. Hasil rekapitulasi dapat dilihat bahwa perhatian anak yang aktif sebanyak 15 anak atau 93,75\%, sedangkan sisanya 1 anak sebesar 6,25\% dari jumlah anak yang tidak aktif. Aspek respon, anak yang aktif sebanyak 15 anak atau 93,75\%, sedangkan sisanya sebanyak 1 anak atau 6,25\%.Sedangkan aspek tanggung jawab anak sebanyak 87,50\%, dan anak yang kurang tanggung jawab terhadap tugas yang diberikan pendidik yang kurang tanggung jawab sebanyak 2 anak atau 6,25\%. Adapun aspek cara anak yang menanggapi yang aktif sebanyak 14 anak atau 87,50\%, dan anak yang tidak aktif sebanyak 2 anak atau 12,50\%. Untuk aspek terakhir yaitu aspek aktifitas anak sebanyak 15 anak atau 93,75\%, sedangkan anak yang tidak bisa sebanyak 1 anak atau sebesar 1,25\%. Aktivitas anak dalam pembelajaran sebagai sarana untuk mengetahui apakah anak merasa senang, dan antusias dalam pembebelajaran kemampuan mencampur warna untuk mengenalkan warna dengan media cat air.

$\underline{\text { Refleksi Siklus II }}$

Analisis terhadap hasil penilaian, hasil observasi dan hasil jurnal, dilakukanoleh peneliti setelah melakukan tindakan siklus II.Adapun tujuannya untuk mengetahui 1) kelebihan dan kekurangan teknik dan media yang dipakai dalam pembelajaran, 2) tindakan anak selama proses pembelajaran, dan 3) tindakan -tindakan pendidik selama mengajar. Pembelajaran kemampuan pencampuran warna dengan metode eksperimen menggunakan media cat air yang dilakukan pendidik pada siklus II. Hal ini tamapak pada minat, ketertarikan, dan antusias anak saat mengikuti pembelajaran. Nilai rata-rata 81,56 pada siklus II, hal ini menyatakan bahwa adanya peningkatan sebesar 6,56\% dari siklus I. Pembelajaran ini masih perlu ditingkatan karena indikator kinerja sudah tercapai, yakni rata-rata 81,56 telah mencapai nilai rata-rata 80 yang ditargetkan, maka pembelajaran telah tuntas.

\section{Pembahasan}

Pembahasan hasil penelitaian didasarkan pada hasil yang didapatkan pada siklus I dan siklus II. Pembahasan ini mengacu pada perolehan skor yang dicapai oleh anak dalam pembelajarannya dalam pembelajaran melukis. Adapun hasilnya mengacu pada perolehan skor hasil penilian dan nontes.

Proses pembelajaran kemampuan anak mencampur warna untuk mengenal warna dengan metode eksperimen dan menggunakanmedia cat air.

Proses kemampuan anak mencampur warna untuk mengenalkan warna denagan media eksperimen dan menggunakan media cat air, yakni aspek intensifnya proses internalisasi 
melakukan pencampuran warna pada siklus I sebanyak 10 anak yang memeperhatikan atau $62,50 \%$ dan termasuk pada kategori cukup, sedangkan pada siklus II terdapat 13 anak yang memperhatikan atau $81,25 \%$ dan masuk kategori sangat baik. Aspek terjadinya proses penjelasan yang kondusif tentang pencampuran warna dengan metode eksperimen dan menggunakan media cat air pada siklus I ada 11 anak yang memperhatian atau 68,75\% dan termasuk kategori baik. Sedangkan pada siklus II ada 14 anak yang memperhatikan atau 87,50\% dan termasuk kategori sangat baik. Aspek intensifnya anak berlatih mencampur warna dengan metode eksperimen dan menggunakan cat air pada siklus I ada 12 anak yang memperhatikan atau 75,00\% dan masuk kategori baik. Sedangkan pada siklus II ada 14 anak yang memperhatikan atau 87,50\% masuk kategori sangat baik. Aspek kondusifnya kondisi anak saatmenyebutkan warna hasil pencampuran warna pada siklus I ada 12 anak yang memperhatikan atau 75,00\% masuk kategori baik. Sedangkan pada siklus II ada 15 anak yang memperhatikan atau 93,75\% masuk pada ketegori sangat baik. Aspek terbangunnnya suasana rileks, sehingga anak terus mengikuti kegiatan pencampuran warna pada siklus I ada 13 anak yang memperhatikan atau 81,23\% dan termasuk kategori baik. Sedangkan pada siklus II ada 15 anak yang memperhatikan atau 93,75\% dan masuk pada kategori sangat baik.

Pengingkatan kemampuan mencampur warna untuk mengenalkan warna dengan metode eksperimen dan menggunakan media cat air.

Kemampuan anak didik pada setiap indikator penilaian kemampuan mencampur warna mengalami peningkatan rata-rata yang dicapai anak. Pada prasiklus, pmbelajaran mencampur warna 57,19, pada siklus I mencampur warna 75,00. Sedangkan pada siklus II memperoleh ratarata 81,56 . Hal ini terlihat adanya peningkatan nilai anak dalam kegiatan pra siklus ke siklus I adalah 17,81, dan dari siklus I ke siklus II adalah 6,56. Adapun pencapaian perkembangan yang diharapkan pada prasiklus hanya $14,58 \%$, kemudian setelah menggunakan metode eksperimen mencampur warna dengan media cat air pada siklus I, maka tergambar 70,83\% sesuai harapan dan pada siklus II mengalami peningkatan sebesar 93,75\%.

\section{PENUTUP}

Setelah kita lihat bahwasannya hasil penelitian pembelajaran mencampur warna dengan metode eksperimen dan menggunakan media cat air adalah sebagai berikut : Proses pembelajaran mencampur warna dengan metode eksperimen dan menggunakan media cat air pada siklus I dan siklus II mengalami peningkatan ke arah yang baik. Hal ini terlihat dari terlihat adanya peningkatann disetiap aspek proses pembelajaran mencampur warna antara lain:1) intensifnya proses internalisasi mencampurkan warna, 2) terjadinya penjelasan yang kondusif tentang kegiatan mencampur warna, 3) intensifnya anak berlatih mencampur warna dengan metode eksperimen dan menggunakan media cat air, 4) kondusifnya anak saat kegiatan mencampur warna untuk mengenalkan warna, 5) terbangunnya suasanayang rileks, sehingga anak terus mengikuti proses pembelajaran atau berlatih setelah kegiatan.

Kemampuan anak dalam setiap indikator penilaian kemampuan mencampur warna mengakami peningkatan rata-rata. Pada prasiklus pembelajaran mencampur warna adalah $57,19 \%$, Sedangkan pada siklus I adalah $75,00 \%$, sedangkan pada Siklus II anak didik memperoleh nilai rata-rata 81,56 . Hal tersebut menunjukkan bahwa nilai anak didik mengalami peningkatan dari kegiatan Prasiklus ke Siklus I adalah 17,81, dan Siklus I ke Siklus II sebesar 6,56. Pencapaian perkembangan yang diharapkan pada kegiatan Prasiklus hanya 14,58\%. Setelah menggunakan dengan metode eksperimen dengan media pewarna cat air pada Siklus maka anak didik yang mendapat nilai diatas perkembangan yang diharapkan adalah 70,83\%, sedangkan pada Siklus II meningkat menjadi 93,75\%. 


\section{DAFTAR PUSTAKA}

Anggraini, S., Jaya, M., \& Sofia, A. (2019). Pengaruh Aktivitas Permainan Finger Painting Terhadap Pengenalan Warna Anak Kelompok B Usia 5-6 Tahun dI TK Bela Bangsa Mandiri Bandar Lampung. Jurnal Pendidikan Anak, 5(1).

Anggreani, C. (2015). Peningkatan Kemampuan Berfikir Kritis Melalui Metode Eksperimen Berbasis Lingkungan. Jurnal Pendidikan Anak usia Dini, 9(2), 343-360.

Damayanti, A. (2020. 2(2)). Meningkatkan Ketrampilan Proses sains Anak Usia 5-6 tahun melalui Metode Eksperimen Mencampur warna di PAUD Permata Hati Desa Jampang . Indonesian Journal of Early Chilhood: Jurnal Dunia Anak Usia Dini , 88-94.

Hernia, H. (2013). Kemampuan Mengenal warna Pada Anak Usia 4-5 Tahun di TK Sigugus III Kecamatan Panjatan kabupaten Kulon Progo. Yogyakarta: Universitas Negeri Yogyakarta.

Khasanah, N., \& Hani'ah, N. (2018). Strategi Peningkatan Kemampuan Anak Usia Dini dalam Mengenal Warna melalui Metode Eksperimen. Atthiflah: Journal of Early Childhood Islamic Education, 5(2), 22-34.

Nugrahani, R. (2013). Pengaruh Metode Eksperimen Pencampuran Warna Terhadap Kemampuan Kognitif Anak Kelompok A Di Tk Dharma Siwi I Surabaya. PAUD Teratai, 2(2).

Riahidayah, I. (2021). Implementasi metode percampuran warna pada kelompok b di taman kanak-kanak. Jurnal PIAUD, 1(01).

Riastuti, R. (2018). Meningkatkan Kemampuan Sains Melalui Permainan Warna Dengan Menggunakan Cat Air Pada Anak Kelompok B TK Negeri Pembina Kabupaten Temanggung. Jurnal Audi: Jurnal Ilmiah Kajian Ilmu Anak dan Media Informasi PAUD, $3(2), 108-117$.

Winarno, W., \& Aryanto, H. (2016). Upaya Meningkatkan Kemampuan Kepekaan Artistik Mahasiswa Pendidikan Seni Rupa Unesa Angkatan 2013 Dengan Cara Melukis Menggunakan Media Cat Air Dan Lilin. Jurnal Dimensi Seni Rupa dan Desain, 13(1), , 77-92.

Yuliani, N., \& Hasibuan, R. (2014). Meningkatkan Kemampuan Motorik halus pada anak melalui Kegiatan Mewarnai Gambar dengan Media Cat Air di Kelompok Bermain Ceria. Ceria PAUD Teratai, 3 (3). 